\title{
Implementation of Talent Management as an Effort to Improve Employee Performance
}

\author{
Suryono Efendi
}

Universitas Nasional, Jakarta, Indonesia

Email: suryono.efendi@yahoo.com

\begin{abstract}
Human capital is critical to the success of every enterprise. Since human resources play a crucial role in an organization, this is critical to maximizing each employee's potential. Effective talent retention cannot be separated from success appraisals. Since talent in this context can be compared to workers' success when carrying out their assigned duties. Since talent management and performance analysis are mutually reinforcing, the next move is to stabilize talent management. Each employee's competencies will be managed, created, and balanced by an end-ofperiod performance assessment. Direct managers, self-assessments, upward or reverse assessments by subordinates or staff members, client assessments, and electronic monitoring are all examples of individuals authorized to make an evaluation. The actions of workers at work and the personality of each employee were evaluated. More generally, what is judged is the sort of job being assessed, the assessment's intent, the assessment's object, which includes job success and the employee's character.
\end{abstract}

\section{Keywords: Talent Management, Employees, Performance, Human Resource Management}

\section{INTRODUCTION}

The development of a company cannot be separated from various supports from both internal and external parties from the company. One of them is derived from human resources (HR) management in a company (Holbeche, 2009). Human resource management is a strategic role in a company where Management of human resources is critical in developing the organization's approach to achieve its goals and transform the strategic plan into action to face competition (Dessler, 2013). Because it is considered a vital role of human resources in an organization, it is essential to develop the potential that exists in each employee. The right step, in this case, is how an organization manages the talents that already exist in each employee. This is not as easy as turning a hand because talent management has not been much organized. But it can be easy when you want to understand and apply it (Horváthová, 2013).

Talking about HR management in general, there has been a paradigm shift or perspective on HR management. The new HR management paradigm views that $\mathrm{HR}$ is an organizational asset or human capital, so it must be managed strategically and proactively (Ellitan, 2002). The strategic position in human resource management, also known as strategic human resource management, is described as the relation between human resource management and the organization's plan for performance improvement. In its implementation, the strategic role in managing HR means that HR managers must elaborate on all the capacities of employees or their human resources, to serve as a competitive advantage for the organization (Ellitan, 2002). Strategic HR management seems to have become a demand to do. Moreover, the changes that occur in the social environment related to the characteristics of today's human resources, namely the information age that is based on usable knowledge and technology. In this era, HR is more of a knowledge worker, which means that HR is currently required to have new knowledge following the changes that are taking place (Sinambela, 2021).

Collings \& Mellahi (2009) state that the discovery of talent management in modern organizations is now considered very important due to the emergence of a modern economy and increasingly strategic business needs. In addition, the younger generation has begun to enter the era of competitive human resources, so the discovery of talent management is said to be a new way of managing human resources and human capital in companies. Talent management is a series of activities carried out by companies to find the right employees and place them in the right place through a process of identification, development, defence, and 
placement in the appropriate position (Lewis \& Heckman, 2006). According to Schullion \& Collings (2011), talent management aims to help improve, retain and develop employees to meet the challenges currently faced by various organizations or companies and enhance organizational performance through meeting organizational needs.

When talent management has been carried out properly, this cannot be separated from an employee performance appraisal activity because talent here can be analogous to the performance performed by employees while carrying out the tasks they are assigned to. This provides context for a comprehensive examination of talent acquisition and employee success appraisals. The following discussion would include the interaction between talent acquisition and performance evaluation, the scope of the employee performance appraisal system, the key components of the employee performance appraisal system, and the employee performance appraisal system's consequences.

\section{METHOD}

This study employs a qualitative approach in conjunction with a literature analysis. This thesis makes little use of mathematics or statistics. Other than that, it places a premium on informative and interpretive research, Denzin \& Lincoln (2011), highlighting that researchers cannot wholly escape what is being studied in researching various constructs in qualitative research. Thus, the findings or results of a study are creations or constructs, which are ultimately in the minds of individuals. A literature review or analysis is a necessary practice in science, especially academic research, where the primary objective is to develop theoretical as well as functional benefits. Literature review functions to build a concept or theory that becomes the basis of study in research. Using this research method, the writer can quickly solve the problem to be researched (Sukardi, 2013).

\section{RESULT AND DISCUSSION}

Talent management is a model of HR development based on talent or talents. Understanding the term talent, in general, can be interpreted as a 'special talent or expertise' (GallardoGallardo, 2018). Gallardo-Gallardo described talent management as the mechanism by which an organization ensures that key potential leaders and roles that support the organization's core competencies (unique abilities and strategic value) are filled. Ritz \& Thom (2011) states that talent management is concerned with finding the right person with the right skills for the correct position. Each individual has different skills. In an organizational context, referring to the definition above, talent is defined as a quality that a particular employee possesses, which is valuable and necessary. Another point of view states that talents have the best quality built and nurtured by the organization for a long-term process. These talents will become the organization's next generation. Talents are not limited to certain areas or levels of employees but can be found at all levels and functions (Rumengan, 2017).

The task that is quite difficult for organizations is identifying individuals who fit into the existing organizational culture. Based on experts' understanding, talent management is a process carried out by company management that manages their talents to be competitive with other companies. Stahl et al. (2012) described six predictor viewpoints when creating an organization with a talent acquisition approach: the competitive viewpoint, the process perspective, the human resource strategy perspective, the growth perspective, the developmental viewpoint), the institutional viewpoint (the cultural viewpoint), and the transition management viewpoint (the change management perspective).

Talent in an organization has several characteristics that differentiate it from employees in general. Several research results in the field of human resources show that talented employees show the main characters, namely:

1. Ability to perform roles

This ability supports an employee to provide superior results in any role that is carried out. This ability distinguishes employees who have broader competencies than specialist abilities.

2. Ability to handle change

the ability to adopt change as part of organizational evolution is one of the characteristics required of talented employees. Talented employees perceive change as a source of challenges and opportunities to prove their competence and abilities. In the face of change, gifted employees will prepare new ways to achieve the desired results.

3. Capacity to learn

The ability to master new knowledge and skills is an essential part of personal development for talented employees. Talented employees always try to expand their knowledge and show the intellectual capacity to absorb new concepts and techniques.

4. Personal profile

Personal profiles can be interpreted as characteristics of talented employees which include: (a) self-confidence based on their ability to master the 
latest changes and this confidence is mastered based on the techniques they adopt to help analyze tasks and develop effective processes for delivering superior performance; (b) skills in communicating both written and oral, and this ability will support them to convey ideas and be accepted by the organization; (c) a combination of self-confidence and communication coupled with logical (reasoning) skills that allow applying a problem-solving approach; and (d) focus or ability to concentrate on the main factors that bring success (Sudjatmiko, 2011).

The purpose of talent management is to develop the best top management in the face of competition, look for good external candidates to fill critical jobs, replenish talents between different units, retain talent through career development opportunities, expand the internal talent pool by focusing on several different employees, building a shared need to have the best players as the key to future business success. Based on talent management, this is very continuous with implementing employee performance appraisals in an organization. Performance or work performance is achieved according to prevailing standards, within a certain period, concerning work and behaviour and actions. Meanwhile, the assessment is the process of assessing an ongoing activity or will take place with a followup action after conducting an evaluation.

Then turning to the notion of performance appraisal, according to Gary Dessler (2013), is evaluating the current and/or past performance of employees relative to their performance standards. According to Anwar Prabu Mangkunegara (2005), an employee's quality and quantity carry out his duties following his responsibilities. According to Viethzal Rivai (2016), performance is a natural behaviour displayed by everyone as a work achievement produced by employees following their role in the company.

The meeting point of these two things is when the assessment process is complete, and then talent management plays a role here. More broadly, there is the mutual desire to produce committed employees with different backgrounds in both psychology and each employee's competencies. Employee appraisal is one of the activities included in talent management activities to get the results that have been achieved for employees in an ongoing organization.

Talent management is a series of activities that focus on managing employee expertise in specific fields within an organization to achieve organizational goals. So, to get the most out of something you want to accomplish in an organization, you must pay attention to these two things, namely neatly organized talent management, by paying attention to an employee assessment that is carried out carefully. It can be said that when talent management carried out by an organization goes according to what has been planned, the employee assessment activities will automatically get satisfactory results, and this makes it easier for an organization to take further action on the employees in it.

The problem related to employee appraisal is who evaluates the performance of the employees in an institution. The most crucial thing in determining who should carry out the assessment is the number and type of working relationships the assessor has with the person being assessed. The quality and quantity of knowledge on tasks vary according to the level of the organization (Hasibuan, 2003). Malayu S.P. Hasibuan argues that the scope of employee appraisal is covered in what, why, where, when, who, and how, which is often abbreviated as $5 \mathrm{~W}+1 \mathrm{H}$. What, what is judged. In this case, what is assessed is employee work behaviour such as loyalty, honesty, cooperation, leadership, commitment, current work, future potential, nature, and work results. Why, why are assessed. Several reasons why this is assessed.

Because to increase the level of satisfaction of employees by giving recognition to their work. To assist the possible development of the personnel concerned. To maintain work potential. To measure the work performance of employees. To calculate the abilities and abilities of employees. To collect data to determine the next staffing program. Where, where the assessment is carried out. The evaluation takes place on the job and off the job; what is meant to be done inside work is formal with a clear systematic, while outside work can be done formally or informally. When, when the assessment is done. The evaluation is carried out both formally and informally. The point is that formal is assessment carried out periodically, whereas informally is an assessment carried out continuously. Who, who will be judged. All workers who do work in an organization. Those who assess their direct superiors, superiors of immediate superiors, and / or a team formed by the organization. How, how to evaluate it. In this case, the focus is more on what methods or techniques will be used and what problems the appraisers face in conducting employee appraisals.

In line with the discussion above, it is clear that the staffing department is centrally responsible for developing a performance appraisal system for all work units in an organization. The primary purpose of this concentration of tasks in the personnel section is to ensure uniformity that is not only reflected in objectivity but also makes documentation more accessible. Whether we realize it or not, the 
performance achievements of employees are also a reflection of the recruitment procedures adopted by the personnel sector. This means that if the recruitment, selection, introduction, and placement system for employees is good, it is very likely that the employees' work performance will be satisfactory. On the other hand, if the system is not good enough, it is possible that the employees' work performance will not be as high as expected. Implicitly this is also directly related to the talent management system carried out in the organization. The whole can be revealed through employee appraisals or employee performance if the assessment is carried out according to mutually agreed procedures.

Four factors must be taken into account before establishing employee performance assessment expectations:

1. Validity refers to the standard's suitability for the type of job being evaluated.

2. The arrangement is a legally binding document; that is, the appraisal criteria has been agreed and endorsed by all workers who will be assessed.

3. Realism implies that the assessment criteria are reasonable, attainable by workers, and consistent with their skills.

4. Objectivity refers to a criterion that is impartial, rational, capable of reflecting the current situation, and resistant to being affected by evaluation bias.

Employees who have competence or talent are then assessed, then a feedback process will be held. In terms of feedback, this can be in the form of rewards, both financial and non-financial, for example, self-actualization. The line of notes obtained during the employee's job will also get feedback and decisions from the personnel to affect employee performance. Things that affect this assessment are the criteria that have to do with the implementation of tasks obtained by each employee and the measure of work performance. Both of these are based on agreed-upon rules. Assessments should be fair representations of employee success. To do this, scoring systems must be job-related, functional, adhere to established requirements, and include a variety of accurate metrics. Job-related means that the device evaluates essential behaviors that contribute to an organization's cleanliness.

By comparison, a method is said to be practical whether it is comprehended or comprehended by workers. Apart from being "business-related" and practical, job performance assessment necessitates the establishment of performance criteria by which work performance can be assessed. Standards must be relevant to the desired outcomes for each job in order to be successful. Additionally, the evaluation process necessitates the use of accurate indicators of job success.

Direct or indirect conclusions may be made during the assessment process. Direct observation happens as the assessor observes the job being completed. In the other hand, the indirect term is used where the appraiser determines that the "imitation" of job execution is less effective. For instance, an assessor monitoring a telephone receiver is considered direct observation, while a written test of a company's emergency call handling protocols is considered indirect observation. Another aspect of success metrics is their objectivity or subjectivity. Objective labor success metrics are those that can be independently verified or reviewed. Subjective tests are judgmental scales that may be developed or tested by others.

The employee performance appraisal process results in an evaluation of the employee's work performance in the past or future by predicting his work performance. As previously mentioned, the accuracy of the assessment mainly depends on the various standards, measures and assessment techniques chosen. When the appraisal is complete and as a document only, it doesn't feel fair for the employees to estimate. In this case, feedback is carried out to employees to improve inappropriate performance and improve good performance.

For this reason, in the feedback process on employee performance appraisal, an appraisal interview is carried out to the employee concerned. An assessment interview is a time during which workers receive input on their previous work success and future. This appraisal interview may provide insight through a variety of interview techniques, including:

1. Inform and offer Attempt Conduct performance reviews and attempt to persuade staff to improve their performance. This technique is more effective when dealing with new hires.

2. Tell-and-Listen Approach Enables staff to articulate a variety of motives, contexts, and defensive emotions regarding their job success. It seeks to alleviate these reactions by counseling on how to succeed.

3. Approach to Problem Solving Identify issues that are interfering with an employee's ability to do his or her job. Following that, attempts are made to correct anomalies through preparation and counseling.

The three approaches can be used according to the situation and conditions when conducting interviews with employees who have been assessed for performance. It is hoped that with the clarity of 
who is considering, what is being evaluated, when to make the assessment, and the feedback or implications for the employees who have been assessed, an organization can quickly improve its human resources within the organization by not ruling out the talent management that has been discussed earlier.

\section{CONCLUSION}

It can be concluded that talent management and performance appraisal have a reciprocal relationship. When the employee performance appraisal results have been obtained, the next step is to consolidate talent management. The competencies that exist in each employee will be managed, developed, and in the end, there will be a performance appraisal at the end of the period. The things that are assessed are the behaviour of the employees while working and the personality that is in each employee. More broadly, what is considered is the type of position being assessed, the purpose of the assessment, the object of the evaluation, which includes work performance and the personal character of the employee.

\section{REFERENCES}

[1] Collings, D. G., \& Mellahi, K. (2009). Strategic Talent Management: A Review And Research Agenda.Human Resource Management Review, 19(4), 304-313.

[2] Denzin, N. K., \& Lincoln, Y. S. (Eds.). (2011). The Sage Handbook of Qualitative Research. Sage.

[3] Dessler, G. (2013). Fundamentals of Human Resource Management. Pearson.

[4] Ellitan, L. (2002). Praktik-Praktik Pengelolaan Sumber Daya Manusia Dan Keunggulan Kompetitif Berkelanjutan. Jurnal Manajemen dan Kewirausahaan, 4(2), 65-76.

[5] Gallardo-Gallardo, E. (2018). The Meaning of Talent in The World of Work. Global Talent Management, 33-58.

[6] Hasibuan, M. S. (2003). Organisasi Dan Motivasi. Jakarta: Bumi Aksara.

[7] Holbeche, L. (2009). Aligning Human Resources and Business Strategy. Routledge.

[8] Horváthová, P. (2011). The Application Of Talent Management At Human Resource Management In Organization. In 3rd International Conference on Information and Financial Engineering, IPEDR (Vol. 12, pp. 5054).
[9] Lewis, R. E., \& Heckman, R. J. (2006). Talent Management: A Critical Review. Human Resource Management Review, 16(2), 139-154.

[10] Mangkunegara, A. A. P. (2005). Evaluasi kinerja SDM. Tiga Serangkai.

[11]Ritz, A., \& Thom, N. (2011). Talent Management. Wiesbaden: Gabler.

[12]Rivai, V. (2016). Manajemen Sumber Daya Manusia Untuk Perusahaan. Rajawali Press.

[13] Rumengan, G. (2017). Kontribusi Manajemen Talenta, Inovasi Dan Keunggulan Kompetitif Dalam Meningkatkan Kinerja Bisnis Perusahaan. Jurnal Riset Bisnis Dan Manajemen, 4(4).

[14] Scullion, H., \& Collings, D. G. (2011). Global Talent Management: Introduction. Routledge.

[15] Sinambela, L. P. (2021). Manajemen Sumber Daya Manusia: Membangun Tim Kerja Yang Solid Untuk Meningkatkan Kinerja. Bumi Aksara.

[16] Stahl, G., Björkman, I., Farndale, E., Morris, S. S., Paauwe, J., Stiles, P., ... \& Wright, P. (2012). Six Principles of Effective Global Talent Management. Sloan Management Review, 53(2), 25-42.

[17] Sudjatmiko, S. (2011). Keep Your Best People. Gramedia.

[18] Sukardi, H. M. (2003). Metodologi Penelitian Pendidikan: Kompetensi Dan Praktiknya. Jakarta: Bumi Aksara.

[19] Wahyudi, S., Hasanudin, H., \& Pangestutia, I. (2020). Asset allocation and strategies on investment portfolio performance: A study on the implementation of employee pension fund in Indonesia. Accounting, 6(5), 839-850.

[20] Nurwulandari, A., Hasanudin, H., \& Melati, M. (2021). Market Reactions on Corporate Actions in Growing and Nongrowing Energy Consuming Companies. International Journal of Energy Economics and Policy, 11(3), 290-295.

[21] Nurwulandari, A., \& Adnyana, I. (2019). Did Inter-Regional Trade Agreements Bring Mutual Benefits? An Empirical Scheme of Indonesian Commodity Exports in Asean-China Free Trade Area. International Journal of Financial Research, 10(6), 241-249.

[22] Hasanudin, H., \& Awaloedin, D. T. (2020). PENGARUH CURRENT RATIO, DEBT TO EQUITY RATIO DAN NET PROFIT MARGIN TERHADAP RETURN SAHAM PADA PERUSAHAAN JASA SUB SEKTOR TELEKOMUNIKASI YANG TERDAFTAR DI 
BEI PERIODE 2012-2018. JURNAL REKAYASA INFORMASI, 9(1), 6-19.

[23] Hasanudin, H. (2021). The Effect of Inflation, Exchange, SBI Interest Rate and Dow Jones Index on JCI on IDX 2013-

2018. Budapest International Research and Critics Institute (BIRCI-Journal): Humanities and Social Sciences, 4(2), 2063-2072.

[24]Wahyudi, S., \& Pangestuti, I. R. D. Managing The Pension Fund To Improve Portfolio Performance: An Empirical Study On Employer Pension Funds In Indonesia. 